\title{
OBESITY AND ITS RELATIONSHIP WITH CANCER: PART I OBESITY
}

\author{
Dr. Shashi K. Agarwal \\ Center for Contemporary and Complementary Cardiology \\ 2227 US Highway 1, Suite 309, North Brunswick, NJ 08902, USA \\ E-mail: usacardiologist@gmail.com
}

\begin{abstract}
Cancer is a lethal disease and a strong barrier to a better life expectancy. It is the first or second leading cause of death before the age of 70 years in 112 of 183 countries. Its incidence and mortality continue to grow rapidly all over the world. This manuscript is divided into four parts. Part I discusses obesity while Part II discusses the relationship between obesity and cancer. Part III and Part IV review the association of obesity on fifteen common cancers.
\end{abstract}

\section{Obesity}

An excessive food intake (surplus energy intake) or insufficient physical activity (low energy expenditure) causes obesity (Galgani et al., 2008). Obesity is an expansion of the adipose tissue due to hypertrophy of pre-existing adipocytes or recruitment (hyperplasia) of adipocyte precursors (Jo et al., 2009). This results in various physiological and pathological changes in the human body (Stenkula \& Erlanson-Albertsson, 2019). The prevalence of obesity has substantially increased worldwide (Caballero, 2007). Obesity now accounts for more than a third of the world's population (Hruby \& Hu, 2015). Its prevalence has nearly tripled between 1975 and 2016 (https://www.who.int/news-room/fact-sheets/detail/obesity-and-overweight.). This dramatic rise in obesity has been attributed to several factors (Finkelstein et al., 2005; Kimbro et al., 2011; Nestle \& Nesheim, 2012; Colabianchi et al., 2014). Technological advancements have led to a decline in manual labor (Finkelstein et al., 2005), and the easy availability of processed and fast foods, and this has resulted in excessive consumption of cheap calories (Nestle \& Nesheim, 2012). Modern built environments also limit outdoor physical activity (Colabianchi et al, 2014) and increase indoor time, often spent watching television or playing on the computer (Kimbro et al., 2011). Overweight and obesity now kill more people globally than underweight (www.cdc.gov). According to the World Health Organization, in 2016, 1.9 billion adults were overweight, while 650 million were obese (www.who.int). In countries like the USA, obesity is now present in almost one-half of the population, with the Centers for Disease Control and Prevention of USA estimating that it affected $42.4 \%$ of the population in $2017-2018$ (CDC, 2021). This increase in excess body weight is also being seen in other parts of the world (https://ec.europa.eu/; GBD, 2015). Overweight (including obesity) in the European Union is estimated to have affected $52.7 \%$ of the adult EU's population in 2019 (https://ec.europa.eu/). In 
the Eastern Mediterranean Region, the prevalence of obesity registered an increase from $15.1 \%$ in 1980 to $20.7 \%$ in 2015 (GBD, 2015). The obesity burden is also affecting the less developed countries (NCD, 2016; Bleich et al., 2017). In 2010-2012 the prevalence of overweight and obesity in Chinese adults was $30.1 \%$ and $11.9 \%$, respectively (PCNH, 2016). In India, it is estimated that the prevalence of overweight and obesity by 2030 , will involve $27.8 \%$, and $5.0 \%$ of all Indians, respectively (Kelly et al., 2008; IIPS, 2017). China, India, Pakistan, and Indonesia are now in the top 10 countries with the highest populations of obesity in the world ( $\mathrm{Ng}$ et al., 2014). Adult obesity has also been increasing at an alarming rate among African countries (Swinburn et al., 2011). Eastern Sudan has a prevalence of $26.8 \%$ for overweight and $32.2 \%$ for obesity (Omar et al., 2020). Uganda has a 17.8\% prevalence of overweight (Kirunda et al., 2015) while in Ethiopia, overweight/obesity increased significantly from $10.9 \%$ in 2000 to $21.4 \%$ in 2016 (Ahmed et al., 2020).

Obesity is also increasing in the younger population (Onywera, 2010; www.who.int; UNICEF, 2020; Danquah et al., 2020). Over 340 million children and adolescents aged 5-19 were overweight or obese in 2016 while 39 million children under the age of 5 were overweight or obese in 2020 (www.who.int). UNICEF estimates that in the pediatric and adolescent population, the prevalence rate of obesity has reached $21.4 \%$ (UNICEF 2021). In the US, the prevalence of obesity was $19.3 \%$ for children and adolescents aged 2-19 years in the years 2017-2018, and 13.4\% among 2- to 5-year-olds (CDC, 2021). According to UNICEF, WHO, and the World Bank, Southern Africa has the highest prevalence of overweight among children under 5 years (14.6\%), followed by Central Asia (11.6\%) and Northern Africa (11.0\%) (Danquah et al., 2020). Cancer risk at an older age may be linked to excess body weight in late adolescence and early adulthood (Genkinger et al., 2015; Park et al., 2018; Colditz \& Peterson, 2018) Prevention of early life obesity can thus also help reduce future cancer. Obesity is an expensive disease (CDC, 2021; Withrow \& Alter, 2011). The CDC estimates that the estimated annual medical cost of obesity in the United States was $\$ 147$ billion in 2008 (CDC, 2021). The global costs are much higher (Withrow \& Alter, 2011).

\section{Body Mass Index}

Actuaries notice an increased mortality of their overweight policyholders after World War II, and the relationship between weight and health became a major subject of epidemiological studies (TIAFT2018). Adolphe Quetelet (1796-1874), a Belgian mathematician, astronomer, and statistician, described a practical index of relative body weight - the ratio of the weight in kilograms divided by the square of the height in meters (or the Quetelet Index) in 1832 (Eknoyan, 2008). This was subsequently termed the Body Mass Index (BMI) in 1972 by Ancel Keys (1904-2004) (Rasmussen, 2019). BMI is nowadays widely used as a measure to define body weight (www.euro.who.int). BMI is categorized into several groups: $<18.5 \mathrm{~kg} / \mathrm{m}^{2}$ (underweight), $18.5-24.9 \mathrm{~kg} / \mathrm{m}^{2}$ (normal weight), and 25 to $29.9 \mathrm{~kg} / \mathrm{m}^{2}$, (overweight). Obesity is defined as a BMI exceeding $30 \mathrm{~kg} / \mathrm{m}^{2}$ and is subclassified into class 1 (30-34.9), class 2 (3539.9 ), and class 3 or severe obesity ( $\geq 40$ ). A BMI $>50 \mathrm{Kg} / \mathrm{m} 2$ is considered morbid obesity (www.euro.who.int). However, BMI may give erroneous results in the elderly (loss of height and aging-related sarcopenia), extremely tall or muscular individuals; and in overweight individuals that self-report their weight (as they tend to underestimate their weight) (Romero-Corral et al., 
2008). BMI may also be unreliable in individuals of Asian descent (WHO, 2004). Asian populations differ from European populations in the percentage of body fat and health risks (Rush et al., 2009). Compared with other ethnic groups, Asians seem to have higher overall fat levels and abdominal fat as well as lower lean body mass for a given BMI (Lim et al., 2011). The International Obesity Task Force has therefore recommended different BMI categories for them (WHO, 2000). These were as follows: underweight $\left(<18.5 \mathrm{~kg} / \mathrm{m}^{2}\right)$, normal (between 18.5 and 23 $\mathrm{kg} / \mathrm{m}^{2}$ ), overweight (between 23 and $25 \mathrm{~kg} / \mathrm{m}^{2}$ ), obese (between 25 and $30 \mathrm{~kg} / \mathrm{m}^{2}$ ), severe obese $\left(\geq 30 \mathrm{~kg} / \mathrm{m}^{2}\right)^{40}$. Chinese may use different guidelines, with one study suggesting overweight is defined as a BMI of $24.0-27.9 \mathrm{~kg} / \mathrm{m} 2$, and obesity is defined as a BMI $\geq 28 \mathrm{~kg} / \mathrm{m} 2$ (Zhou, 2002).

\section{Abdominal obesity}

BMI may not be a reliable indicator of body fat content and distribution (Allott \& Hursting, 2015). It has been estimated by several studies that about $10 \%$ of the US population has a normal BMI but increased body fat content (Romero-Corral et al., 2010; Main et al., 2010). This may occur if there is excess adipose tissue (AT) deposition around the abdominal viscera and inside the intra-abdominal solid organs (Tchernof \& Després., 2013). Vague in 1947 first suggested the deleterious relationship between subcutaneous and abdominal fat distribution and cardiometabolic complications (Garg, 2004). Subcutaneous AT is rich in mitochondria and is highly vascularized and innervated. It is mainly involved in heat production (Saely, 2011). Visceral AT is primarily white and serves as a store for excess energy (Saely, 2011). However, it also acts in an autocrine, paracrine, or endocrine organ (Coelho et al., 2016; Finelli, 2020). Visceral AT and its macrophages produce pro-inflammatory cytokines like tumor necrosis factor-alpha and interleukin-6 (Finelli, 2020). It also is associated with an increased expression of fibroblast growth factor 21and insulin-like growth factor-binding protein-5, and decreased levels of hepatocytes, insulin-like-1 growth factors, and adinopectin (Coelho et al., 2016). Adiponectin is anti-inflammatory and helps reduce body fat and to improve hepatic and peripheral insulin sensitivity (Abenavoli \& Peta, 2014). The cytokines induce increased inflammation and higher insulin resistance, resulting in endothelial dysfunction (Zhang, 2008). There is also increased pro-atherogenic dyslipidemia (Liu et al., 2010) and a prothrombotic effect (Dosquet et al., 1995). The increased insulin resistance (McLaughlin et al., 2011) and associated atherosclerotic and thrombogenic profile leads to an increase in diabetes mellitus and cardiovascular diseases in these patients (Després, 2011; Yokokawa et al., 2021). Conversely, the subcutaneous adipose tissue in the abdomen and thigh may be protective, as it is associated with a lower risk for insulin resistance (Taksali, 2008; McLaughlin et al., 2011). Visceral fat accumulation is usually independent of age, overall obesity, or the amount of subcutaneous fat (Tchernof \& Després, 2013). However, it appears to be more prominent in white men, African American women, and Asian Indian and Japanese men and women (Hamdy et al., 2006). Visceral fat is also closely related to tumorigenesis and the progression of tumors (Crudele et al., 2021).

Central obesity can be objectively ascertained by several anthropometric measurements (Donohoe et al., 2014). The commonest in use is the waist circumference (WC) (NPTD, 2001). Its value for detecting central or visceral obesity has been confirmed by several subsequent studies (Yusuf et al., 2004). WC should ideally be $<102 \mathrm{~cm}$ in males and $<88 \mathrm{~cm}$ in females 
when measured to the nearest $0.1 \mathrm{~cm}$ at the umbilical level in a standing position. In the Asian populations, these numbers are $<85 \mathrm{~cm}$ for males and, $<80 \mathrm{~cm}$ for females. Higher values indicate visceral obesity. Many researchers have also used another anthropometric measurement, waist to hip ratio and the normal values for this are 0.85 or less for women and 0.9 or less for men (Wakabayashi, 2013). The waist-height ratio is calculated as WC divided by height. A ratio $<0.5$ indicates no visceral obesity and $\geq 0.5$ is consistent with visceral obesity and an increased risk for many cardiometabolic diseases and cancer (Ashwell et al., 2012).

\section{Obesity and Health}

Obesity deleteriously affects human health. Obesity often causes several health problems in children (Gurnani et al., 2015; Sahoo et al. 2015) including early puberty (De Leonibus et al., 2012), menstruation irregularities (Witchel et al., 2019), sleep disorders (Marcus et al. 2012), hypertension (Wühl, 2019), diabetes (Flodmark, 2018), and non-alcoholic fatty liver disease (Shaunak et al., 2021). Childhood obesity may be associated with reduced self-esteem, low body image, anxiety and depression, poor peer relationships, academic underachievement, and systematic discrimination (Rankin et al., 2016; Topçu et al., 2016). These psychological effects often negatively modify a child's future. Further, childhood obesity also predicts adult obesity (NCD 2017). Obesity in children may therefore also implant the seed for the future development of several non-communicable diseases (Bhave et al., 2004). Elevated BMI in adults is associated with several chronic diseases - these include cardiovascular disorders (Parto \& Lavie), diabetes mellitus (Schnurr et al. 2020), depression (Luppino et al., 2010), chronic kidney disease (Ting et al., 2009), obstructive sleep apnea (Tuomilehto et al., 2013), osteoarthritis (Losina E et al., 2013), gout (McCormick et al., 2020), nonalcoholic fatty liver disease (Polyzos et al., 2017), osteoporosis (Friebe \& Peters (2005), and infertility (Talmor \& Dunphy, 2015);

Kahn \& Brannigan, 2017). It causes increased complications related to pregnancy (Schummers et al., 2015). Obesity may also lead to psychosocial distress (Aldossari et al., 2021), and obese people may have low self-esteem and feelings of rejection (KavehFarsani et al., 2020). They often have heightened anxiety (Heidari-Beni et al., 2021), body image dissatisfaction (MakaraStudzińska 2009), and may face weight bias and sigma (Spahlholz 2016). Weight sigma affects approximately $20 \%-40 \%$ of obese persons (Spahlholz 2016). Stigma may also be exhibited by health care providers against obese patients (Gupta 2020). Weight-influenced stigma is stressful (Tomiyama 2014) and often internalized, and this results in adverse health outcomes (Hunger et al., 2015; Pearl et al., 2020). Obesity may also lead to disqualification from the US military (Christeson et al., 2010). It reduces the health quality of life (Meixner et al., 2020). According to recent data, obesity was related to 148 million disability-adjusted life years and 4.72 million deaths worldwide (GBD, 2017). It a major cause of preventable death second only behind smoking (GBD, 2017). It has been estimated that obese individuals (BMI of $>30-35 \mathrm{~kg} / \mathrm{m}^{2}$ ) lose about 2-4 years of life while those with severe obesity (BMI $>40 \mathrm{~kg} / \mathrm{m}^{2}$, lose about 8-10 years of life (CPS, 2009). Obesity care is also expensive and imparts a high economic burden on society (OECD 2019). In the US alone, obesity-related direct and indirect health care costs are over $\$ 150$ billion or even $\$ 190$ billion yearly (Cawley \& Meyerhoefer, 2012) while in Canada, it costs 1.27-11.08 billion Canadian dollars annually (Tran et al., 2013). Obesity is also closely linked with cancer (Avgerinos et al., 2019) and this is discussed in the next three parts of this manuscript. 


\section{Health diseases/medications causing obesity}

Several health conditions and medication can also cause obesity. Implicated medical disorders include hypothyroidism (Hoogwerf \& Nuttall,1984), prolactinoma (Ali \& Mirza 2021), polycystic ovarian syndrome (Rasquin et al., 2021), depression (Blaine, 2008; Islam el al.,2020), and Cushing's syndrome (www.endocrineweb.com). Cancer survivors may also gain excess body weight more rapidly than the general population (Greenlee 2016). Several prescription drugs are also associated with weight gain. Psychotropic drugs especially clozapine and olanzapine are notorious in this regard (Bak et al., 2014; Zhang et al., 2016). Anti-diabetic medications like insulin, sulfonylurea, and thiazolidinediones may cause substantial weight gain when compared to placebo (Domecq et al., 2015). $\beta$-blockers, commonly used to treat hypertension and some cardiovascular disorders, often result in excess body weight (Sharma et al., 2001). Anti-epileptic drugs, especially valproate and carbamazepine, are weight promoting (Ben-Menachem, 2007). Chronic corticoid therapy is associated with weight gain in up to $70 \%$ of all patients (Curtis et al., 2006).

\section{Obesity Paradox}

In the general population, mortality is higher in both the underweight and overweight, when compared with those with normal weight - indicating a 'U-shaped' relationship (Flegal et al., 2013; Global BMI Mortality (2016). Some diseases however demonstrate improved survival in overweight/obese individuals when compared with normal-weight individuals, while there is still increased mortality in the underweight (Cao et al., 2012; Spelta et al., 2018). This reverse "Jshaped" curve is referred to as the "obesity paradox" and has been described in several other chronic diseases such as heart failure (Khan et al., 2021), coronary artery disease (Akin \& Nienaber, 2015), chronic obstructive pulmonary disease (Chittal et al., 2015), and end-stage kidney disease (Park et al., 2014). It has also been noted in several acute conditions such as pneumonia (Nie et al., 2014; Cichon et al., 2021), sepsis (Cichon et al., 2021), and acute respiratory distress syndrome (Liu et al., 2021). Several hypotheses have been advanced to explain this phenomenon. Studies have found that patients demonstrating the obesity paradox have increased lean mass (Lee et al., 2018), despite the obesity, and a better cardiorespiratory fitness (Barry et al., 2018). Other mechanisms may also be involved. Obesity paradox has also been noted with some cancers - this is discussed in Part II.

To summarize, obesity has become a pandemic (Meldrum et al., 2017). It is growing in all ages, populations, and ethnic groups, irrespective of the socioeconomic status. It is associated with severe morbidity and mortality, especially due to cardiovascular diseases and diabetes mellitus (Poirier et al., 2006; Tobias et al., 2014). It is also strongly associated with most cancers (KrupaKotara \& Dakowska, 2021).

Acknowledgment: None

Funding: None

Conflict of interest: None 


\section{REFERENCES}

Abenavoli L, Peta V. (2014) Role of adipokines and cytokines in non-alcoholic fatty liver disease. Rev Recent Clin Trials. 9(3):134-140.12.

Ahmed KY, Abrha S, Page A, et al. (2020) Trends and determinants of underweight and overweight/obesity among urban Ethiopian women from 2000 to 2016. BMC Public Health. Aug 24;20(1):1276. doi: 10.1186/s12889-020-09345-6.

Akin I, Nienaber CA. (2015) 'Obesity paradox' in coronary artery disease. World J Cardiol. 7: 603-608. doi:10.4330/wjc.v7.i10.603.

Aldossari KK, Shubair MM, Al-Ghamdi S, et al. (2021) The association between overweight/obesity and psychological distress: A population based cross-sectional study in Saudi Arabia. Saudi J Biol Sci. May 28(5):2783-2788. doi: 10.1016/j.sjbs.2021.02.008.

Ali M, Mirza L. (2021) Morbid Obesity Due to Prolactinoma and Significant Weight Loss After Dopamine Agonist Treatment. AACE Clin Case Rep. Mar:11;7(3):204-206. doi: 10.1016/j.aace.2021.01.004.

Allott EH, Hursting SD. (2015) Obesity and cancer: mechanistic insights from transdisciplinary studies. Endocr Relat Cancer. 22:R365-86.

Ashwell M, Gunn P, Gibson S. (2012) Waist-to-height ratio is a better screening tool than waist circumference and BMI for adult cardiometabolic risk factors: systematic review and meta-analysis. Obes Rev. Mar;13(3):275-86. doi: 10.1111/j.1467-789X.2011.00952.x.

Avgerinos KI, Spyrou N, Mantzoros CS, Dalamaga M. (2019) Obesity and cancer risk: Emerging biological mechanisms and perspectives. Metabolism. Mar;92:121-135. doi: 10.1016/j.metabol.2018.11.001.

Bak M, Fransen A, Janssen J, Van Os J, Drukker M. (2014) Almost all antipsychotics result in weight gain: A meta-analysis. PLoS One 9(4):1-19. 10.1371/journal.pone.0094112.

Barry VW, Caputo JL, Kang M. (2018) The Joint Association of Fitness and Fatness on Cardiovascular Disease Mortality: A Meta-Analysis. Prog Cardiovasc Dis. JulAug;61(2):136-141. doi: 10.1016/j.pcad.2018.07.004.

Ben-Menachem E. (2007) Weight issues for people with epilepsy--a review. Epilepsia. 48 Suppl 9:42-45.

Bhave S, Bavdekar A, Otiv M. (2004) IAP National Task Force for Childhood, Prevention of Adult Diseases: Childhood Obesity. Indian Pediatr. 41:559-75.

Blaine B. (2008) Does depression cause obesity?: A meta-analysis of longitudinal studies of depression and weight control. J Health Psychol. Nov;13(8):1190-7. doi: $10.1177 / 1359105308095977$.

Bleich SN, Vercammen KA, Zatz LY, et al. (2017) Review Interventions to prevent global childhood overweight and obesity : a systematic review. LANCET Diabetes Endocrinol 8587:1-15.

Caballero B. (2007) The global epidemic of obesity: an overview. Epidemiologic Reviews. 29(1):1-5. doi: 10.1093/epirev/mxm012.

Cao C, Wang R, Wang J, et al. (2012) Body mass index and mortality in chronic obstructive pulmonary disease: a meta-analysis. PLoS ONE 7: e43892. doi:10.1371/journal.pone.0043892.

Cawley J, Meyerhoefer C. (2012) The medical care costs of obesity: an instrumental variables approach. J Health Econ. 31:219-30.

CDC (2021). https://www.cdc.gov/obesity/data/adult. - accessed October 6, 2021. 
Chittal P., Babu A.S., Lavie C.J. (2015) Obesity paradox: does fat alter outcomes in chronic obstructive pulmonary disease? COPD. 12(1):14-18.

Christeson W, Taggart A, Mesner-Zidell S. (2010) Too Fat to Fight: Retired Military Leaders Want Junk Food out of America's Schools. Mission: Readiness; Washington, DC. Available from: http://cdn.missionreadiness.org/MR_Too_Fat_to_Fight-1.pdf.

Cichon I, Ortmann W, Santocki M, Opydo-Chanek M, Kolaczkowska E. (2021) Scrutinizing Mechanisms of the 'Obesity Paradox in Sepsis': Obesity Is Accompanied by Diminished Formation of Neutrophil Extracellular Traps (NETs) Due to Restricted NeutrophilPlatelet Interactions. Cells. 2021;10(2):384. Published Feb 12. doi:10.3390/cells10020384.

Coelho P., Almeida J., Prudêncio C., Fernandes R., Soares R. (2016) Effect of Adipocyte Secretome in Melanoma Progression and Vasculogenic Mimicry. J. Cell. Biochem. 117:1697-1706. doi: 10.1002/jcb.25463.

Colabianchi N, Coulton CJ, Hibbert JD, et al. (2014) Adolescent self-defined neighborhoods and activity spaces: spatial overlap and relations to physical activity and obesity. Health Place. May;27:22-9. doi: 10.1016/j.healthplace.2014.01.004.

Colditz G.A., Peterson L.L. (2018) Obesity and cancer: evidence, impact, and future directions. Clin Chem. 64: 154-162.

CPS. Collaboration PS. (2009) Body-mass index and cause-specific mortality in 900000 adults: collaborative analyses of 57 prospective studies. Lancet 373:1083-96. 10.1016/S01406736(09)60318-4.

Corrales-Medina VF, Valayam J, Serpa JA, et al. (2011) The obesity paradox in communityacquired bacterial pneumonia. Int J Infect Dis 15: e54-e57. doi:10.1016/j.ijid.2010.09.011.

Crudele L, Piccinin E, Moschetta A. (2021) Visceral Adiposity and Cancer: Role in Pathogenesis and Prognosis. Nutrients.Jun 19;13(6). doi: 10.3390/nu13062101.

Curtis JR, Westfall AO, Allison J, et al. (2006) Population-based assessment of adverse events associated with long-term glucocorticoid use. Arthritis and rheumatism. 55(3):420-426.

Danquah, F.I., Ansu-Mensah, M., Bawontuo, V. et al. (2020) Prevalence, incidence, and trends of childhood overweight/obesity in Sub-Saharan Africa: a systematic scoping review. Arch Public Health 78, 109 https://doi.org/10.1186/s13690-020-00491-2.

De Leonibus C, Marcovecchio ML, Chiarelli F. (2012) Update on statural growth and pubertal development in obese children. Pediatr Rep. 4:e35. 10.4081/pr.2012.e35.

Després JP. (2007) Cardiovascular disease under the influence of excess visceral fat. Crit Pathw Cardiol. Jun;6(2):51-9. doi: 10.1097/HPC.0b013e318057d4c9.

Domecq JP, Prutsky G, Leppin A, et al. (2015) Clinical review: Drugs commonly associated with weight change: a systematic review and meta-analysis. J Clin Endocrinol Metab. 100(2):363-370.

Donohoe CL, O'Farrell NJ, Doyle SL, Reynolds JV. (2014) The role of obesity in gastrointestinal cancer: evidence and opinion. Therap Adv Gastroenterol. 7(1):38-50. 10.1177/1756283X13501786.

Dosquet, Christine; Weill, Dominique; Wautier, Jean-Luc. (1995) Cytokines and Thrombosis. Journal of Cardiovascular Pharmacology. 25:S13-S19.

Eknoyan G. (2009) Adolphe quetelet (1796-1874)--the average man and indices of obesity. Nephrol Dial Transplant. 23:47-51. 
Finelli C. (2020) "A New Endocrine "Gland": Adipose Tissue". EC Endocrinology and Metabolic Research SI.02: 07-09.

Finkelstein EA, Ruhm CJ, \& Kosa KM (2005). Economic causes and consequences of obesity. Annual Review of Public Health, 26, 239-257.

Flegal KM, Kit BK, Orpana H, et al. (2013) Association of all-cause mortality with overweight and obesity using standard body mass index categories: a systematic review and metaanalysis. JAMA. 309: 71-82. doi:10.1001/jama.2012.113905.

Flodmark CE. (2018) Prevention Models of Childhood Obesity in Sweden. Obes Facts. 11(3):257-262. doi:10.1159/000482009.

Friebe H, Peters A. (2005) Ubergewicht und Osteoporose [Obesity and osteoporosis]. Orthopade. Jul;34(7):645-51. German. doi: 10.1007/s00132-005-0821-X.

Islam, K. M. A., Khan, M. A. U., Azhar, S., Ahmed, M. R., Khurram, S., Masood, H., \& Farooq, L. (2020). Comparison Of In Vitro Activity of Colistin with Ceftolozane/Tazobactam against Multi Drug Resistant Pseudomonas Aeruginosa "A Last Line Treatment against Mdr". American International Journal of Multidisciplinary Scientific Research, 6(3), 1-7.

Galgani, J., Ravussin, E. (2008) Energy metabolism, fuel selection and body weight regulation. Int J Obes 32, S109-S119. https://doi.org/10.1038/ijo.2008.246.

Garg A. (2004) Regional adiposity and insulin resistance. J. Clin. Endocrinol. Metab. 89:42064210. doi: 10.1210/jc.2004-0631.

GBD 2015 Eastern Mediterranean Region Obesity Collaborators. Burden of obesity in the Eastern Mediterranean Region: findings from the Global Burden of Disease 2015 study. Int J Public Health 63(Suppl 1):165-176.

GBD 2017 Risk Factor Collaborators. Global, regional, and national comparative risk assessment of 84 behavioural, environmental and occupational, and metabolic risks or clusters of risks for 195 countries and territories, 1990-2017: a systematic analysis for the Global Burden of Disease Study 2017. Lancet. 2018;392(10159):1923-1994. doi:10.1016/S0140-6736(18)32225-6.

Genkinger J.M.,Kitahara C.M.;Bernstein L. et al. (2015) Central adiposity, obesity during early adulthood, and pancreatic cancer mortality in a pooled analysis of cohort studies. Ann Oncol. 26: 2257-2266.

Global BMI Mortality Collaboration, Di Angelantonio E, Bhupathiraju S, et al. (2016) Bodymass index and all-cause mortality: individual-participant-data meta-analysis of 239 prospective studies in four continents. Lancet 388: 776-786. doi:10.1016/S01406736(16)30175-1

Greenlee H, Shi Z, Sardo Molmenti CL, Rundle A, Tsai WY. (2016) Trends in Obesity Prevalence in Adults With a History of Cancer: Results From the US National Health Interview Survey, 1997 to 2014. J Clin Oncol 2016;34:3133-40.

Gupta N, Bombak A, Foroughi I, Riediger N. (2020) Discrimination in the health care system among higher-weight adults: evidence from a Canadian national cross-sectional survey. Health Promot Chronic Dis Prev Can. Nov/Dec;40(11-12):329-335. doi: 10.24095/hpcdp.40.11/12.01.

Gurnani M, Birken C, Hamilton J. (2015) Childhood Obesity: Causes, Consequences, and Management. Pediatr Clin North Am. Aug;62(4):821-40. doi: 10.1016/j.pcl.2015.04.001. 
Hamdy O, Porramatikul S, Al-Ozairi E. (2006) Metabolic obesity: the paradox between visceral and subcutaneous fat. Curr Diabetes Rev. 2006 Nov;2(4):367-73. doi: $10.2174 / 1573399810602040367$.

Heidari-Beni M, Azizi-Soleiman F, Afshar H, et al. (2021) Relationship between obesity and depression, anxiety and psychological distress among Iranian health-care staff. East Mediterr Health J. 2021 Apr 27;27(4):327-335. doi: 10.26719/emhj.20.132.

Hoogwerf BJ, Nuttall FQ. (1984) Long-term weight regulation in treated hyperthyroid and hypothyroid subjects. Am J Med. Jun;76(6):963-70. doi: 10.1016/0002-9343(84)908428.

Hruby A, Hu FB. (2015) The epidemiology of obesity: a big picture. Pharmacoeconomics. 2015;33:673-689.

Eurostat (2021) https://ec.europa.eu/eurostat/statisticsexplained/index.php?title=Overweight_and_obesity_-_BMI_statistics $\quad-\quad$ accessed October 8.

Hunger JM, Major B, Blodorn A, Miller CT. (2015) Weighed down by stigma: How weightbased social identity threat contributes to weight gain and poor health. Soc Personal Psychol Compass. Jun;9(6):255-268. doi: 10.1111/spc3.12172.

IIPS (2017). India. International Institute for Population Sciences (IIPS) and ICF.5-7.

Jo J, Gavrilova O, Pack S, Jou W, et al. (2009) Hypertrophy and/or Hyperplasia: Dynamics of Adipose Tissue Growth. PLoS Comput Biol. Mar;5(3):e1000324. doi: 10.1371/journal.pcbi.1000324.

Kahn BE, Brannigan RE. (2017) Obesity and male infertility. Curr Opin Urol. Sep;27(5):441445. doi: 10.1097/MOU.0000000000000417.

KavehFarsani Z, Kelishadi R, Beshlideh K. (2020) Study of the effect of family communication and function, and satisfaction with body image, on psychological well-being of obese girls: the mediating role of self-esteem and depression. Child Adolesc Psychiatry Ment Health. Oct 12;14:39. doi: 10.1186/s13034-020-00345-3.

Kelly T., Yang W., Chen C.-S., Reynolds K. \& He J. (2008) Global burden of obesity in 2005 and projections to 2030. Int. J. Obes. 32, 1431-1437.

Khan A, Van Iterson EH, Laffin LJ. (2021) The obesity paradox in heart failure: What is the role of cardiorespiratory fitness? Cleve Clin J Med. Aug 2;88(8):449-458. doi: 10.3949/ccjm.88a.20098.

Kimbro RT, Brooks-Gunn J, McLanahan S. (2011) Young children in urban areas: links among neighborhood characteristics, weight status, outdoor play, and television watching. Soc Sci Med. Mar;72(5):668-76. doi: 10.1016/j.socscimed.2010.12.015.

Kirunda BE, Fadnes LT, Wamani H, van den Broeck J, Tylleskär T. (2015) Population-based survey of overweight and obesity and the associated factors in peri-urban and rural Eastern Uganda. BMC Public Health. 15: 1168. doi: 10.1186/s12889-015-2506-7.

Krupa-Kotara K., Dakowska D. (2021) Impact of obesity on risk of cancer. Central Eur. J. Public Health. 29:38-44. doi: 10.21101/cejph.a5913.

Lee DH, Keum N, Hu FB, Orav EJ, Rimm EB, Willet WC. Giovannucci. (2018) Predicted lean body mass, fat mass, and all cause and cause specific mortality in men: prospective US cohort study. BMJ. 362:k2575. doi: 10.1136/bmj.k2575.

Lim U, Ernst T, Buchthal SD, et al. (2011) Asian women have greater abdominal and visceral adiposity than Caucasian women with similar body mass index. Nutr Diabetes. 1:e6. doi: 10.1038/nutd.2011.2. 
Liu J, Fox CS, Hickson DA, May WD, et al. (2010) Impact of abdominal visceral and subcutaneous adipose tissue on cardiometabolic risk factors: the Jackson Heart Study. J Clin Endocrinol Metab. Dec;95(12):5419-26. doi: 10.1210/jc.2010-1378.

Liu Y, Song M, Huang L, Zhu G. (2021) "Obesity Paradox" in Acute Respiratory Distress Syndrome Among Patients Undergoing Cardiac Surgery: A Retrospective Study. Med Sci Monit. Aug 25;27:e931808. doi: 10.12659/MSM.931808.

Losina E, Weinstein AM, Reichmann WM, et al. (2013) Lifetime risk and age at diagnosis of symptomatic knee osteoarthritis in the US Arthritis Care Res (Hoboken) 2013;65:703711. doi: 10.1002/acr.21898.

Luppino FS, de Wit LM, Bouvy PF, et al. (2010) Overweight, obesity, and depression: a systematic review and meta-analysis of longitudinal studies. Arch Gen Psychiatry. Mar;67(3):220-9. doi: 10.1001/archgenpsychiatry.2010.2.

Main M.L., Rao S.C., O'Keefe J.H. (2010)Trends in obesity and extreme obesity among US adults. JAMA. 303:1695-1696.

Makara-Studzińska M, Zaborska A. (2009) Otyłość a obraz własnego ciała [Obesity and body image]. Psychiatr Pol. Jan-Feb;43(1):109-14. Polish.

Marcus CL, Brooks LJ, Draper KA, et al. (2012) American Academy of Pediatrics. Diagnosis and management of childhood obstructive sleep apnea syndrome. Pediatrics. Sep;130(3):e714-55. doi: 10.1542/peds.2012-1672.

McCormick N, Rai SK, Lu N, Yokose C, Curhan GC, Choi HK. (2020) Estimation of Primary Prevention of Gout in Men Through Modification of Obesity and Other Key Lifestyle Factors. JAMA Netw Open. Nov 2;3(11):e2027421. doi: 10.1001/jamanetworkopen.2020.27421.

McLaughlin T, Lamendola C, Liu A, Abbasi F. (2011) Preferential fat deposition in subcutaneous versus visceral depots is associated with insulin sensitivity. J Clin Endocrinol Metab. 96(11):E1756-E1760. doi:10.1210/jc.2011-0615.

Meixner L, Cohrdes C, Schienkiewitz A, Mensink GBM. (2020) Health-related quality of life in children and adolescents with overweight and obesity: results from the German KIGGS survey. BMC Public Health. Nov 16;20(1):1722. doi: 10.1186/s12889-020-09834-8.

Meldrum DR, Morris MA, Gambone JC. (2017) Obesity pandemic: causes, consequences, and solutions-but do we have the will? Fertil Steril. Apr;107(4):833-839. doi: 10.1016/j.fertnstert.2017.02.104.

NCD 2016. Risk Factor Collaboration (NCD-RisC). (2016) Trends in adult body-mass index in 200 countries from 1975 to 2014: a pooled analysis of 1698 population-based measurement studies with 19.2 million participants. Lancet. 387(10026):1377-1396. doi: 10.1016/S0140-6736(16)30054-X.

NCD 2017. Risk Factor Collaboration (NCD-RisC). (2017) Worldwide trends in body-mass index, underweight, overweight, and obesity from 1975 to 2016: a pooled analysis of 2416 population-based measurement studies in 128.9 million children, adolescents, and adults. Lancet, 390, pp. 2627-2642

Nestle M, \& Nesheim MC (2012). Why calories count: from science to politics. Health Affairs, $31,9$.

Ng M, Fleming T, Robinson M, Thomson B, Graetz N, Margono C, et al. (2014) Global, regional, and national prevalence of overweight and obesity in children and adults during 1980-2013: a systematic analysis for the Global Burden of Disease Study 2013. Lancet. 384:766-81. doi: 10.1016/S0140-6736(14)60460-8. 
Nie W, Zhang Y, Jee SH, et al. (2014) Obesity survival paradox in pneumonia: a meta-analysis. BMC Med. 4; 12: 61. doi:10.1186/1741-7015-12-61.

NPTD. (2001) Nutrition in the Prevention and Treatment of Disease. Edited by: Ann M. Coulston, Cheryl L. Rock And Elaine R. Monsen.

OECD (2019) - Organisation for Economic Co-operation and Development . The heavy burden of obesity: The economics of prevention, OECD Health Policy Studies.

Omar SM, Taha Z, Hassan AA, Al-Wutayd O, Adam I. (2020) Prevalence and factors associated with overweight and central obesity among adults in the Eastern Sudan. PLoS One. 15(4):e0232624. doi:10.1371/journal.pone.0232624.

Onywera VO. (2010) Childhood obesity and physical inactivity threat in Africa: strategies for a healthy future. Glob Health Promot. Jun;17(2 Suppl):45-6. doi: $10.1177 / 1757975910363937$.

Park J, Ahmadi SF, Streja E, et al. (2014) Obesity paradox in end-stage kidney disease patients. Prog Cardiovasc Dis. 4; 56: 415-425. doi:10.1016/j.pcad.2013.10.005.

Park Y. Colditz G.A. (2018) Diabetes and adiposity: a heavy load for cancer. Lancet Diabetes Endocrinol. 6: 82-83.

Parto P, Lavie CJ. (2017) Obesity and CardiovascularDiseases. Curr Probl Cardiol. Nov;42(11):376-394. doi: 10.1016/j.cpcardiol.2017.04.004.

PCNH, (2016) Bureau of Disease Prevention and Control National Health and Family Planning Commission of the PRC. Report on Chinese Residents' Chronic Diseases and Nutrition (2015) People's Medical Publishing House; Beijing, China.

Pearl RL, Puhl RM, Himmelstein MS, Pinto AM, Foster GD. (2020) Weight Stigma and Weight-Related Health: Associations of Self-Report Measures Among Adults in Weight Management. Ann Behav Med. Nov 1;54(11):904-914. doi: 10.1093/abm/kaaa026.

Poirier P, Giles TD, Bray GA, et al. (2006) Obesity and cardiovascular disease: pathophysiology, evaluation, and effect of weight loss: an update of the 1997 American Heart Association Scientific Statement on Obesity and Heart Disease from the Obesity Committee of the Council on Nutrition, Physical Activity, and Metabolism. Circulation 113:898-918. 10.1161/CIRCULATIONAHA.106.171016.

Polyzos SA, Kountouras J, Mantzoros CS. (2017) Adipose tissue, obesity and non-alcoholic fatty liver disease. Minerva Endocrinol. Jun;42(2):92-108. doi: 10.23736/S03911977.16.02563-3.

Rankin J, Matthews L, Cobley S et al. (2016) Psychological consequences of childhood obesity: psychiatric comorbidity and prevention. Adolesc Health Med Ther 7: 125-46.

Rasmussen N. Downsizing obesity: (2019) On Ancel Keys, the origins of BMI, and the neglect of excess weight as a health hazard in the United States from the 1950s to 1970s. J Hist Behav Sci. Oct;55(4):299-318. doi: 10.1002/jhbs.21991.

Rasquin Leon LI, Anastasopoulou C, Mayrin JV. (2021) Polycystic Ovarian Disease. Jul 21. In: StatPearls [Internet]. Treasure Island (FL): StatPearls Publishing; 2021 Jan-.

Romero-Corral A, Somers VK, Sierra-Johnson J, et al. (2008) Accuracy of body mass index in diagnosing obesity in the adult general population. Int J Obes (Lond) 32:959-66.

Romero-Corral A., Somers V.K., Sierra-Johnson J. et al. (2010) Normal weight obesity: A risk factor for cardiometabolic dysregulation and cardiovascular mortality. Eur. Heart J. 31:737-746. 
Rush EC, Freitas I, Plank LD. (2009) Body Size, Body Composition and Fat Distribution: Comparative Analysis of European, Maori, Pacific Island and Asian Indian Adults. Br J Nutr 102:632-41. 10.1017/S0007114508207221.

Saely C.H., Geiger K., Drexel H. (2011) Brown versus white adipose tissue: A mini-review. Gerontology. 58:15-23. doi: 10.1159/000321319.

Sahoo K, Sahoo B, Choudhury AK, Sofi NY, Kumar R, Bhadoria. AS. (2015) Childhood obesity: causes and consequences. J Family Med Prim Care. 4:187-92. 10.4103/22494863.154628

Schnurr T.M., Jakupović H., Carrasquilla G.D., et al. (2020) Obesity, unfavourable lifestyle and genetic risk of type 2 diabetes: A case-cohort study. Diabetology. 63:1324-1332. doi: 10.1007/s00125-020-05140-5.

Schummers L, Hutcheon JA, Bodnar LM, Lieberman E, Himes KP. (2015) Risk of adverse pregnancy outcomes by prepregnancy body mass index: a population-based study to inform prepregnancy weight loss counseling. Obstet Gynecol. 125(1):133-143.

Sharma AM, Pischon T, Hardt S, Kunz I, Luft FC. (2001) Hypothesis: Beta-adrenergic receptor blockers and weight gain: A systematic analysis. Hypertension. 37(2):250-254.

Shaunak M, Byrne CD, Davis N, et al. (2021). Non-alcoholic fatty liver disease and childhood obesity. Arch Dis Child. Jan;106(1):3-8. doi: 10.1136/archdischild-2019-318063.

Spahlholz J, Baer N, König HH, Riedel-Heller SG, Luck-Sikorski C. (2016) Obesity and discrimination-A systematic review and meta-analysis of observational studies. Obes Rev.17:43-55.

Spelta F, Fratta Pasini AM, Cazzoletti L, et al. (2018) Body weight and mortality in COPD: focus on the obesity paradox. Eat Weight Disord 2018; 23: 15-22. doi:10.1007/s40519017-0456-z.

Stenkula KG, Erlanson-Albertsson C. (2018) Adipose cell size: importance in health and disease. Am J Physiol Regul Integr Comp Physiol. Aug 1;315(2):R284-R295. doi: 10.1152/ajpregu.00257.2017.

Swinburn BA, Sacks G, Hall KD, et al. (2011) The global obesity pandemic: Shaped by global drivers and local environments. Lancet.378: 804-814. doi: 10.1016/S01406736(11)60813-1.

Taksali SE, Caprio S, Dziura J, et al. (2008) High visceral and low abdominal subcutaneous fat stores in the obese adolescent: a determinant of an adverse metabolic phenotype. Diabetes 57:367-371,

Talmor A, Dunphy B. (2015) Female obesity and infertility. Best Pract Res Clin Obstet Gynaecol. May;29(4):498-506. doi: 10.1016/j.bpobgyn.2014.10.014.

Tchernof A, Després JP. (2013) Pathophysiology of human visceral obesity: an update. Physiol Rev. Jan;93(1):359-404. doi: 10.1152/physrev.00033.2011.

TIAFT (2018). https://tiaft2018.org/obesity/body-mass-index-22-1-undertaker/ - mentioned.

Ting SM, Nair H, Ching I, Taheri S, Dasgupta I. (2009) Overweight, obesity and chronic kidney disease. Nephron Clin Pract.112(3):c121-7; discussion c127. doi: 10.1159/000214206.

Tobias DK, Pan A, Jackson CL, et al. (2014) Body-mass index and mortality among adults with incident type 2 diabetes. N Engl J Med 370:233-44. 10.1056/NEJMoa1304501.

Tomiyama AJ. (2014) Weight stigma is stressful. A review of evidence for the Cyclic Obesity/Weight-Based Stigma model. Appetite. Nov;82:8-15. doi: 10.1016/j.appet.2014.06.108. 
Topçu S, Orhon FS, Tayfun M, Uçaktürk SA, Demirel F. (2016) Anxiety, depression, and selfesteem levels in obese children: a case-control study. J Pediatr Endocrinol Metabol. 29:357-61. 10.1515/jpem-2015-0254.

Tran BX, Nair AV, Kuhle S, Ohinmaa A, Veugelers PJ. (2013) Cost analyses of obesity in Canada: scope, quality, and implications. Cost Eff Resour Alloc. 11(1):3. doi: 10.1186/1478-7547-11-3.

Tuomilehto H, Seppä J, Uusitupa M. (2013) Obesity and obstructive sleep apnea--clinical significance of weight loss. Sleep Med Rev. Oct;17(5):321-9. doi: 10.1016/j.smrv.2012.08.002.

UNICEF. (2020) data.unicef.org/wp-content/uploads/2020/03/Joint-Malnutrition-Estimates2020-brochure.pdf - accessed October 5, 2021.

Wakabayashi Ichiro. (2013) Necessity of Both Waist Circumference and Waist-to-Height Ratio for Better Evaluation of Central Obesity. Metabolic Syndrome and Related Disorders.11(3):189-194. doi: 10.1089/met.2012.0131.

WHO (2000) World Health Organization, International Obesity Task Force. The Asian-Pacific perspective: Redefining obesity and its treatment. Geneva, Switzerland: WHO Western Pacific Region, 2000.

WHO (2004) WHO Expert Consultation. Appropriate body-mass index for Asian populations and its implications for policy and intervention strategies. Lancet. Jan 10;363(9403):15763. doi: 10.1016/S0140-6736(03)15268-3.

Witchel SF, Burghard AC, Tao RH, Oberfield SE. (2019) The diagnosis and treatment of PCOS in adolescents. Curr Opin Pediatr. 31:562-9. 10.1097/MOP.0000000000000778.

Withrow D, Alter DA. (2011) The economic burden of obesity worldwide: a systematic review of the direct costs of obesity. Obes Rev 12:131-41.

Wühl E. (2019) Hypertension in childhood obesity. Acta Paediatr. Jan;108(1):37-43. doi: 10.1111/apa.14551.

Yokokawa H, Fukuda H, Saita M, et al. (2021) An association between visceral or subcutaneous fat accumulation and diabetes mellitus among Japanese subjects. Diabetol Metab Syndr. Apr 14;13(1):44. doi: 10.1186/s13098-021-00646-3.

Yusuf S., Hawken S., Ounpuu S., et al. (2004) INTERHEART Study Investigators Effect of potentially modifiable risk factors associated with myocardial infarction in 52 countries (the INTERHEART study): Case-control study. Lancet. 364:937-952.

Zhang C. (2008) The role of inflammatory cytokines in endothelial dysfunction. Basic Res Cardiol. Sep;103(5):398-406. doi: 10.1007/s00395-008-0733-0.

Zhang JP, Lencz T, Zhang RX, et al. (2016) Pharmacogenetic Associations of Antipsychotic Drug-Related Weight Gain: A Systematic Review and Meta-analysis. Schizophr Bull 42(6):1418-37. 10.1093/schbul/sbw058.

Zhou BF. (2002) Predictive values of body mass index and waist circumference for risk factors of certain related diseases in Chinese adults - study on optimal cut-off points of body mass index and waist circumference in Chinese adults. Biomed Environ Sci.15:83-96.

\section{Copyrights}

Copyright for this article is retained by the author(s), with first publication rights granted to the journal. This is an open-access article distributed under the terms and conditions of the Creative Commons Attribution license (http://creativecommons.org/licenses/by/4.0/). 